\title{
A Convenient Synthesis of New 3,7-Diphenylthieno[3,2-e]bis[1,2,4] triazolo[4,3-a:4',3'-c]pyrimidine Derivatives by Oxidative Cyclization Using Alumina-supported Calcium Hypochlorite
}

\author{
Hoon Young Son and Yang-Heon Song* \\ Department of Chemistry, Mokwon University, Daejeon 302-729, Korea. *E-mail: yhsong@mokwon.ac.kr \\ Received May 15, 2010, Accepted June 15, 2010
}

\begin{abstract}
New 3,7-diphenylthieno[3,2-e]bis[1,2,4]triazolo[4,3-a:4',3'-c]pyrimidine derivatives were easily synthesized at room temperature in good yield by the oxidative cyclization of thienopyrimidinyl hydrazones with alumina-supported calcium hypochlorite $\left(\mathrm{Ca}(\mathrm{OCl})_{2} / \mathrm{Al}_{2} \mathrm{O}_{3}\right)$.
\end{abstract}

Key Words: 1,2,4-Triazole, Calcium hypochlorite, Thienotriazolopyrimidine, Oxidative cyclization, Alumina

\section{Introduction}

The heterocyclic compounds containing 1,2,4-triazole moiety continue to attract considerable interest because of their broad biological activities such as antimicrobial, ${ }^{1}$ antifungal, ${ }^{2}$ antiinflammatory, ${ }^{3}$ and antibacterial ${ }^{4}$ agents. Furthermore, it has been noticed that introduction of an additional ring to the triazolopyrimidine system which is one of the fused 1,2,4-triazole compound tends to exert profound influence in conferring new biological activities in these molecules. For instance, thienotriazolopyrimidinone $\mathbf{1}$ and pyrazolotriazolopyrimidine $\mathbf{2}$ derivatives of tricyclic heterocyclic compounds as shown in Fig. 1 have been recently synthesized for xanthine oxidase inhibitor ${ }^{5}$ and adenosine $A_{2 A} / A_{3}$ receptor antagonists, ${ }^{6}$ respectively. The compound 3, 3,9-diphenyl-bis-1,2,4-triazolo[4,3-a][4',3'-c] pyrimidine derivatives, were also found to possess strong antibacterial activity. ${ }^{7}$ Recently, we have designed and synthesized a series of thienotriazolopyrimidine compounds $\mathbf{4}$ and $\mathbf{5}$ of potential biological interest using iodobenzene diacetate. ${ }^{8}$

One of the useful methods for the preparation of fused 1,2,4triazoles is based on oxidative cyclization of the fused heterocyclic hydrazones. This oxidative cyclization has been carried<smiles>O=c1[nH]c2sccc2c2nc(-c3ccccc3)nn12</smiles>

1
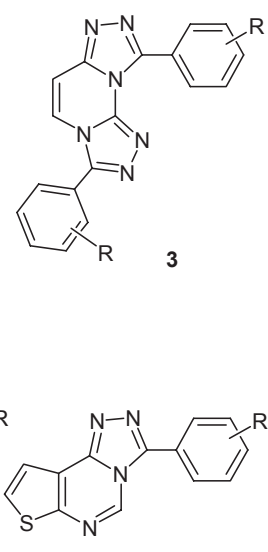

4
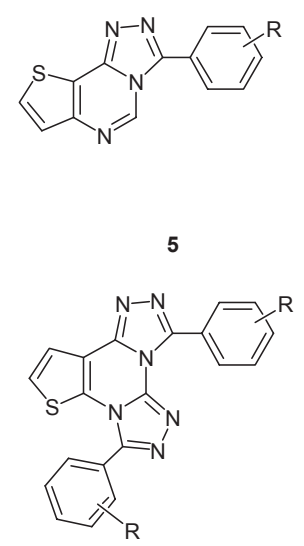

6
Figure 1. Heterocyclic compounds containing 1,2,4-triazole. out using various reagents of bromine, ${ }^{9,10}$ lead tetraacetate, ${ }^{11}$ phosphorus oxychloride $^{11}$ or thionyl chloride. ${ }^{12}$ These reagents are often associated with several restrictions such as toxicity, poor yield, and drastic reaction conditions. In order to overcome these drawbacks, the oxidant ferric chloride, ${ }^{6,13,14}$ chloranil, ${ }^{5,15}$ iodobenzene diacetate $\mathrm{e}^{7,8}$ and copper dichloride ${ }^{16}$ have been introduced. However since the reactions using reagents listed above still have some limitations, such as need of aqueous workup, use of acetic acid, separation of iodobenzene, and removal of copper ions as a water-soluble complex, the more convenient and efficient alternative reagent is required.

As a continuation of our research work on thienopyrimidines and thienopyridines with biological interest, ${ }^{17}$ we wish to report herein the synthesis of new 3,7-diphenylthieno[3,2-e]bis [1,2,4] triazolo[4,3-a:4',3'-c]pyrimidine derivatives $\mathbf{6 a - h}$ using alumina-supported calcium hypochlorite $\left(\mathrm{Ca}(\mathrm{OCl})_{2} / \mathrm{Al}_{2} \mathrm{O}_{3}=1: 1\right.$, grounded mixture) in oxidative cyclization reaction. The use of alumina-supported calcium hypochlorite as a heterogeneous oxidant in this reaction has advantage of enhanced reaction rate and yield, simple work-up, low cost, and eco-friendly reagent.

\section{Results and Discussion}

Initially, we studied, as shown in Table 1, the oxidative properties of calcium hypochlorite on alumina in cyclization reaction of thienopyrimidinyl hydrazone yielding the fused 1,2,4triazole $4 \mathbf{a}(\mathrm{R}=\mathrm{H})$ as a model reaction. The reaction was carried out in dichloromethane at room temperature varying the amounts of alumina-supported calcium hypochlorite (Table 1, Entries 1-4). Among the results obtained, a maximum yield of $78 \%$ for $\mathbf{4 a}$ in $1 \mathrm{hr}$ was achieved with 1:3 molar ratio of hydrazone to calcium hypochlorite. Isolation of the crude product was easily carried out by simple filtration and solvent evaporation, and pure compound $\mathbf{4} \mathbf{a}$ was produced by recrystallization. No further improvement was obtained in yield and reaction time when the reaction was performed in different solvents and reaction temperatures (Table 1, Entries 5-7). The use of calcium hypochlorite without alumina resulted in decreased yield and longer reaction time (Table 1, Entries 8-11). Almost same yield $(73 \%)$ was also obtained for the synthesis of $\mathbf{5 a}(\mathrm{R}=\mathrm{H})$ under 
Table 1. Optimization of reaction conditions for the synthesis of 4a using calcium hypochlorite

\begin{tabular}{|c|c|c|c|c|c|}
\hline Entry & Oxidant $^{a}{ }^{a}\left(\right.$ Sub:Oxi) ${ }^{b}$ & Solvent & Time (h) & Temperature & Yield $(\%)^{c}$ \\
\hline 1 & $\mathrm{Ca}(\mathrm{OCl})_{2} / \mathrm{Al}_{2} \mathrm{O}_{3},(1: 1)$ & $\mathrm{CH}_{2} \mathrm{Cl}_{2}$ & 4 & $\mathrm{rt}$ & 56 \\
\hline 2 & $\mathrm{Ca}(\mathrm{OCl})_{2} / \mathrm{Al}_{2} \mathrm{O}_{3},(1: 2)$ & $\mathrm{CH}_{2} \mathrm{Cl}_{2}$ & 2 & $\mathrm{rt}$ & 69 \\
\hline 3 & $\mathrm{Ca}(\mathrm{OCl})_{2} / \mathrm{Al}_{2} \mathrm{O}_{3},(1: 3)$ & $\mathrm{CH}_{2} \mathrm{Cl}_{2}$ & 1 & $\mathrm{rt}$ & 78 \\
\hline 4 & $\mathrm{Ca}(\mathrm{OCl})_{2} / \mathrm{Al}_{2} \mathrm{O}_{3},(1: 4)$ & $\mathrm{CH}_{2} \mathrm{Cl}_{2}$ & 1 & $\mathrm{rt}$ & 76 \\
\hline 5 & $\mathrm{Ca}(\mathrm{OCl})_{2} / \mathrm{Al}_{2} \mathrm{O}_{3},(1: 3)$ & $\mathrm{CHCl}_{3}$ & 1 & $\mathrm{rt}$ & 75 \\
\hline 6 & $\mathrm{Ca}(\mathrm{OCl})_{2} / \mathrm{Al}_{2} \mathrm{O}_{3},(1: 3)$ & $\mathrm{CHCl}_{3}$ & 1 & reflux & 69 \\
\hline 7 & $\mathrm{Ca}(\mathrm{OCl})_{2} / \mathrm{Al}_{2} \mathrm{O}_{3},(1: 3)$ & $\mathrm{CH}_{3} \mathrm{CN}$ & 1 & reflux & 70 \\
\hline 8 & $\mathrm{Ca}(\mathrm{OCl})_{2},(1: 1)$ & $\mathrm{MeOH}$ & 4 & $\mathrm{rt}$ & 34 \\
\hline 9 & $\mathrm{Ca}(\mathrm{OCl})_{2},(1: 2)$ & $\mathrm{CH}_{2} \mathrm{Cl}_{2}$ & 4 & $\mathrm{rt}$ & 46 \\
\hline 10 & $\mathrm{Ca}(\mathrm{OCl})_{2},(1: 3)$ & $\mathrm{CH}_{2} \mathrm{Cl}_{2}$ & 4 & $\mathrm{rt}$ & 49 \\
\hline 11 & $\mathrm{Ca}(\mathrm{OCl})_{2},(1: 3)$ & $\mathrm{MeOH}$ & 3 & reflux & 61 \\
\hline
\end{tabular}

${ }^{a}$ Oxidant $\mathrm{Ca}(\mathrm{OCl})_{2} / \mathrm{Al}_{2} \mathrm{O}_{3}$ is a grounded mixture of calcium hypochlorite and alumina $(\mathrm{w} / \mathrm{w}=1) .{ }^{b}$ Molar ratio of substrate (hydrazone) and oxidant (calcium hypochlorite). ${ }^{c}$ Yield of isolated product.

Table 2. Triazole compounds from the oxidative cyclization of heterocyclic hydrazones using $\mathrm{Ca}(\mathrm{OCl})_{2} / \mathrm{Al}_{2} \mathrm{O}_{3}$

\begin{tabular}{|c|c|c|c|c|c|}
\hline Entry & Hydrazone & Time (h) & Triazole & Yield $(\%)^{a}$ & $\mathrm{mp}\left({ }^{\circ} \mathrm{C}\right)$ (Lit.) \\
\hline 1 & & 1 & & 75 & 242-244 (8) \\
\hline 2 & & 1 & & 70 & $263-265(8)$ \\
\hline 3 & & 1 & & 68 & $247-249(16)$ \\
\hline 4 & & 1 & & 63 & $206-208$ (16) \\
\hline 5 & & 2 & & 60 & 193-195 (5) \\
\hline 6 & & 2 & & 71 & $174-176(13)$ \\
\hline 7 & & 2 & & 60 & $150-152(18)$ \\
\hline
\end{tabular}


<smiles>NC(=O)c1ccsc1N</smiles>

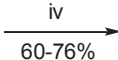

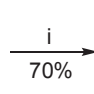<smiles>C=C1NC(=O)c2ccsc2N1</smiles><smiles>[R]1ccc(/C=N/Nc2nc(N/N=C/c3ccccc3)c3ccsc3n2)cc1</smiles>

11<smiles>Clc1nc(Cl)c2ccsc2n1</smiles>

9

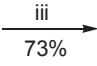<smiles>NNc1nc(NN)c2ccsc2n1</smiles>

10

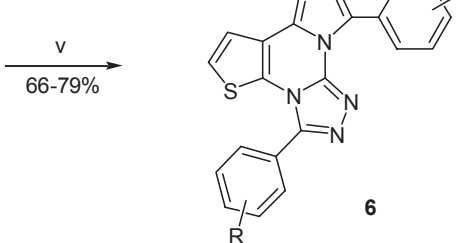

R: a, H; b, 4-Cl; c, 4-Me; d, 4-Br; e, 4-MeO; f, 3-Cl; g, 3-Me; h, 3-Br

Scheme 1. Synthesis of 3,7-diphenylthieno[3,2-e]bis[1,2,4]triazolo[4,3- $a: 4^{\prime}, 3^{\prime}$ '-c]pyrimidine derivatives 6a-h. Reagent and condition: i, urea, $200{ }^{\circ} \mathrm{C}$; ii, $\mathrm{POCl}_{3}, \mathrm{~N}, \mathrm{~N}$-dimethylaniline, reflux; iii, hydrazine hydrate, $\mathrm{EtOH}$, reflux; iv, $\mathrm{RCHO}$, cat. piperidine, $\mathrm{EtOH}, \mathrm{reflux} ; \mathrm{v}, 5$ eq. $\mathrm{Ca}(\mathrm{OCl})_{2} /$ $\mathrm{Al}_{2} \mathrm{O}_{3}, \mathrm{CH}_{2} \mathrm{Cl}_{2}, \mathrm{rt}$

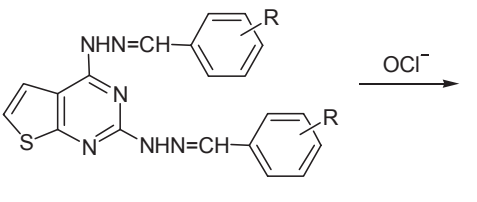

11
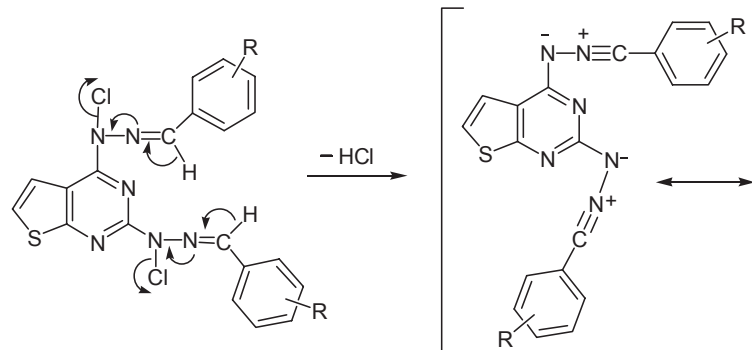

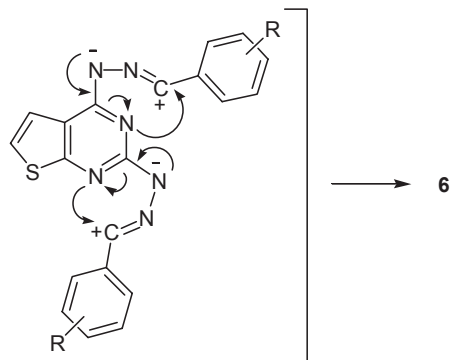

Scheme 2. Proposed mechanism of oxidative cyclization of $\mathbf{1 1}$ by hypochlorite

the optimum condition ( 3 eq. of $\mathrm{Ca}(\mathrm{OCl})_{2} / \mathrm{Al}_{2} \mathrm{O}_{3}, \mathrm{CH}_{2} \mathrm{Cl}_{2}$, rt). These yields are comparable with those obtained using iodobenzene diacetate (4a: $85 \%$ and $\mathbf{5 a}$ : $75 \%$ in $1 \mathrm{hr}$ ). ${ }^{8}$

To further probe the synthetic scope of this reagent for the fused 1,2,4-triazole, we investigated the oxidative cyclization of other heterocyclic hydrazones to afford the corresponding 1,2,4-triazolo derivatives (Table 2). Heterocyclization of the various hydrazones could be easily carried out at room temperature for $1-2 \mathrm{~h}$, and the crude product from the reaction mixture was also easily separated by simple filtration. Evaporation and recrystallization of crude products gave the pure 1,2,4-triazolo compounds in good yields (60 - 75\%). Comparison of the reactivities of the tested hydrazones showed that the oxidative cyclization was not strongly affected by the substituent $\mathrm{R}$ and the nature of the heterocyclic moiety. Notably, the yield of triazole remained unchanged when the phenyl group in the hydrazone was replaced by an $n$-propyl group (Table 2, Entries 7). Therefore, we have successfully developed a convenient and efficient method for the oxidative cyclization reaction of heterocyclic hydrazones.

As shown Scheme 1, we then applied this useful agent to the synthesis of new 3,7-diphenylthieno[3,2-e]bis[1,2,4]triazolo[4,3-a:4',3'-c]pyrimidine derivatives 6a-h. The key intermediate, 2,4-hydrazinylthieno[2,3- $d]$ pyrimidine (10), ${ }^{19}$ was prepared starting from 2 -aminothiophene-3-carboxamide $(7)^{17 \mathrm{j}}$ via $\mathbf{8}$ and $\mathbf{9}$ according to the modified procedures by Robba, $\mathrm{M}^{20}$ That is, heating 7 with 4 eq of urea in fusion gave the thieno $[2,3-d]$ pyrimidine-2,4-(1H,3H)-dione $(\mathbf{8})$ in $70 \%$ yield. Chlori- nation of $\mathbf{8}$ was carried out with $\mathrm{POCl}_{3}$ and $N, N$-dimethylaniline under reflux in the usual way to get 9 in $63 \%$ yield. Then, treatment of $\mathbf{8}$ with an excess hydrazine hydrate in refluxing ethanol afforded $\mathbf{1 0}$ in $73 \%$ yield. Subsequent reaction of $\mathbf{1 0}$ with appropriate aryl aldehydes in refluxing ethanol in the presence of catalytic amount of few drops of piperidine yielded the corresponding hydrazones (11a-h) in 60 - 76\% yields. The oxidative cyclization of $\mathbf{1 1 a}-\mathbf{h}$ to the tetracyclic compounds $\mathbf{6 a - h}$ was successfully carried out by treatment of 11a-h with 5 eq of alumina-supported calcium hypochlorite to afford the corresponding 3,7-diphenylthieno[3,2-e] bis[1,2,4] triazolo [4,3-a:4',3'-c] pyrimidine derivatives $\mathbf{6 a - h}$ in $66-79 \%$ yields. For instance, when a solution of 11a in dichloromethane was treated with 5 eq of alumina-supported calcium hypochlorite at room temperature for $2 \mathrm{~h}$, the crude product was obtained as solid after simple workup of filtration and evaporation. The crude product was purified by recrystallization to give pure compound $\mathbf{6 a}$ in $70 \%$ yield. When compared to the oxidative cyclization of monohydrazones (Table 2), the oxidative ring closure of dihydrazones 11a-h required longer reaction time $(2 \mathrm{~h})$ and more amount of $\mathrm{Ca}(\mathrm{OCl})_{2} / \mathrm{Al}_{2} \mathrm{O}_{3}(5 \mathrm{eq})$ for complete reaction. Any excess of $\mathrm{Ca}(\mathrm{OCl})_{2} / \mathrm{Al}_{2} \mathrm{O}_{3}$ beyond 5 eq did not show any further increase in conversion and yield. The structures of all new compounds were confirmed by elemental analyses and spectroscopic studies.

Although the mechanism of cyclization is not certain, it is expected to be similar to the proposed mechanisms of other related oxidative cyclizations of pyrazolopyrimidinyl hydrazones $^{6}$ and quinazolinyl hydrazones ${ }^{13}$ by ferric chloride or the 
oxidative cyclizations of thienopyrimidinyl hydrazones ${ }^{8}$ by iodobenzene diacetate. The conversion of $\mathbf{1 1}$ to $\mathbf{6}$ was considered to proceed via cyclization of the corresponding nitrilimine intermediates through the electrophilic attack of hypochlorite on 11 followed by elimination of $\mathrm{HCl}$ (Scheme 2).

\section{Conclusions}

In summary, we have demonstrated here an efficient and convenient procedure for the synthesis of various fused 1,2,4triazoles and new 3,7-diphenylthieno[3,2-e]bis[1,2,4]triazolo [4,3-a:4',3'-c]pyrimidine derivatives $\mathbf{6 a - h}$ by oxidative cyclization using alumina-supported calcium hypochlorite. The advantage of our protocol is easy workup, mild reaction conditions, fast reaction rates, and good yields, which make the method a useful contribution to the present methodologies.

\section{Experimental}

Melting points were determined in capillary tubes on Büchi apparatus and are uncorrected. Each compound of the reactions was checked on thin-layer chromatography of Merck Kieselgel $60 \mathrm{~F}_{254}$ and purified by column chromatography Merck silica gel (70 - 230 mesh). The ${ }^{1} \mathrm{H}$ NMR spectra were recorded on Bruker DRX-300 FT NMR spectrometer (300 MHz) with $\mathrm{Me}_{4} \mathrm{Si}$ as internal standard and chemical shifts are given in ppm $(\delta)$. IR spectra were recorded using an Excalibur FTS-3000 FT IR spectrophotometer. Electron ionization mass spectra were recorded on a HP $59580 \mathrm{~B}$ spectrometer. Elemental analyses were performed on a Carlo Erba 1106 elemental analyzer.

General procedure for the preparation of 11a-h. A mixture of the hydrazine $\mathbf{1 0}(5 \mathrm{mmol})$ and the appropriate aldehyde (5 mmol) in absolute ethanol $(20 \mathrm{~mL})$ containing a few drops of piperidine, was refluxed for $5 \mathrm{~h}$. After cooling and evaporation, the solid products formed were filtered, dried and recrystallized from methanol.

2,4-Bis-(2-benzylidenehydrazinyl)thieno[2,3- $d]$ pyrimidine (11a): $65 \%$ Yield, mp $257-259{ }^{\circ} \mathrm{C}$; IR (KBr) 3110 and 3080 $(\mathrm{NH}), 1460(\mathrm{C}=\mathrm{N}) \mathrm{cm}^{-1} ;{ }^{1} \mathrm{H}$ NMR (DMSO- $\left.d_{6}\right) \delta 11.58(\mathrm{~s}, 1 \mathrm{H}$, $\mathrm{NH}), 10.95(\mathrm{~s}, 1 \mathrm{H}, \mathrm{NH}), 8.29(\mathrm{~s}, 1 \mathrm{H},(\mathrm{s}, 1 \mathrm{H}, \mathrm{N}=\mathrm{CH}), 8.15(\mathrm{~s}, 1 \mathrm{H}$, $\mathrm{N}=\mathrm{CH}), 7.91(\mathrm{~d}, 1 \mathrm{H}, J=5.9 \mathrm{~Hz}$, thiophene $\mathrm{H}-6), 7.72(\mathrm{~d}, 2 \mathrm{H}$, H-2' and H-6'), 7.67 (d, 2H, H-2"' and H-6"), 7.52-7.34 (m, 6H, H-3', H-4', H-5', H-3", H-4"' and H-5"), 7.27 (d, 1H, J= $5.9 \mathrm{~Hz}, \mathrm{H}-5)$; $\mathrm{MS}(\mathrm{m} / \mathrm{z}) 372\left(\mathrm{M}^{+}\right)$; Anal. Calcd. for $\mathrm{C}_{20} \mathrm{H}_{16} \mathrm{~N}_{6} \mathrm{~S}$ : C, 64.50; H, 4.33, N, 22.56. Found: C, 64.28; H, 4.54; N, 22.37.

2,4-Bis-(2-(4-chlorobenzylidene)hydrazinyl)thieno[2,3-d] pyrimidine (11b): $76 \%$ Yield, mp $281-283{ }^{\circ} \mathrm{C}$; IR (KBr) 3115 and $3070(\mathrm{NH}), 1454(\mathrm{C}=\mathrm{N}) \mathrm{cm}^{-1} ;{ }^{1} \mathrm{H} \mathrm{NMR}\left(\mathrm{DMSO}-d_{6}\right) \delta 11.64$ $(\mathrm{s}, 1 \mathrm{H}, \mathrm{NH}), 11.06(\mathrm{~s}, 1 \mathrm{H}, \mathrm{NH}), 8.29(\mathrm{~s}, 1 \mathrm{H},(\mathrm{s}, 1 \mathrm{H}, \mathrm{N}=\mathrm{CH})$, $8.11(\mathrm{~s}, 1 \mathrm{H}, \mathrm{N}=\mathrm{CH}), 7.90(\mathrm{~d}, 2 \mathrm{H}, \mathrm{H}-2$ ' and $\mathrm{H}-6$ ') $7.74(\mathrm{~d}, 2 \mathrm{H}$, H-2" and H-6"'), 7.58-7.52 (m, 3H, H-6, H-3' and H-5'), 7.48 (d, 2H, H-3" and H-5"), 7.28 (d, 1H, J=5.9 Hz, H-5); MS $(\mathrm{m} / \mathrm{z}) 441\left(\mathrm{M}^{+}\right)$; Anal. Calcd. for $\mathrm{C}_{20} \mathrm{H}_{14} \mathrm{Cl}_{2} \mathrm{~N}_{6} \mathrm{~S}$ : C, 54.43; $\mathrm{H}$, 3.20, N, 19.04. Found: C, 54.21; H, 3.06; N, 19.23.

2,4-Bis-(2-(4-methylbenzylidene)hydrazinyl)thieno[2,3-d] pyrimidine (11c): $68 \%$ Yield, mp $253-255^{\circ} \mathrm{C}$; IR (KBr) 3122 and $3087(\mathrm{NH}), 1458(\mathrm{C}=\mathrm{N}) \mathrm{cm}^{-1} ;{ }^{1} \mathrm{H}$ NMR (DMSO- $\left.d_{6}\right) \delta$ 11.51 (s, 1H, NH), 10.87 (s, 1H, NH), 8.24 (s, 1H, N=CH), $8.09(\mathrm{~s}, 1 \mathrm{H}, \mathrm{N}=\mathrm{CH}), 7.88(\mathrm{~d}, 1 \mathrm{H}, J=5.9 \mathrm{~Hz}$, thiophene $\mathrm{H}-6)$, 7.61 (d, 2H, H-2' and H-6'), 7.56 (d, 2H, H-2"' and H-6"), 7.30 (d, 2H, H-3' and H-5'), 7.25 (m, 3H, H-5, H-3"' and H-5"), 2.41(s, 6H, $2 \mathrm{Me})$; $\mathrm{MS}(\mathrm{m} / \mathrm{z}) 400\left(\mathrm{M}^{+}\right)$; Anal. Calcd. for $\mathrm{C}_{22} \mathrm{H}_{20} \mathrm{~N}_{6} \mathrm{~S}$ : C, 65.98; H, 5.03, N, 20.98. Found: C, 66.20; H, $4.88 ; \mathrm{N}, 20.77$.

2,4-Bis-(2-(4-bromobenzylidene)hydrazinyl)thieno[2,3- $d$ ] pyrimidine (11d): $65 \%$ Yield, mp $283-285^{\circ} \mathrm{C}$; IR (KBr) 3115 and $3080(\mathrm{NH}), 1460(\mathrm{C}=\mathrm{N}) \mathrm{cm}^{-1} ;{ }^{1} \mathrm{H}$ NMR (DMSO- $\left.d_{6}\right) \delta 11.65$ (s, 1H, NH), 10.87 (s, 1H, NH), 8.25 (s, $1 \mathrm{H}, \mathrm{N}=\mathrm{CH}), 8.11$ (s, $1 \mathrm{H}, \mathrm{N}=\mathrm{CH}), 7.88(\mathrm{~d}, 1 \mathrm{H}, J=5.9 \mathrm{~Hz}$, thiophene $\mathrm{H}-6), 7.82(\mathrm{~d}$, 2H, H-2' and H-6'), 7.72 (d, 2H, H-2"' and H-6"), 7.68 (d, 2H, H-3' and H-5'), 7.64 (d, 2H, H-3"' and H-5"'), 7.28 (d, 1H, J=5.9 $\mathrm{Hz}, \mathrm{H}-5)$; MS (m/z) $530\left(\mathrm{M}^{+}\right)$; Anal. Calcd. for $\mathrm{C}_{20} \mathrm{H}_{14} \mathrm{Br}_{2} \mathrm{~N}_{6} \mathrm{~S}$ : C, 45.30; H, 2.66, N, 15.85. Found: C, 45.19; H, 2.75; N, 15.61 .

2,4-Bis-(2-(4-methoxybenzylidene)hydrazinyl)thieno[2,3-d] pyrimidine (11e): $68 \%$ Yield, mp $274-277{ }^{\circ} \mathrm{C}$; IR (KBr) 3113 and $3076(\mathrm{NH}), 1457(\mathrm{C}=\mathrm{N}) \mathrm{cm}^{-1} ;{ }^{1} \mathrm{H}$ NMR $\left(\mathrm{DMSO}-d_{6}\right) \delta 11.44$ (s, 1H, NH), 10.78 (s, 1H, NH), 8.22 (s, 1H, N=CH), 8.09 (s, $1 \mathrm{H}, \mathrm{N}=\mathrm{CH}), 7.89(\mathrm{~d}, 1 \mathrm{H}, J=5.9 \mathrm{~Hz}$, thiophene $\mathrm{H}-6), 7.66(\mathrm{~d}$, 2H, H-2' and H-6'), 7.60 (d, 2H, H-2"' and H-6"), 7.20 (d, 1H, $J=5.9 \mathrm{~Hz}, \mathrm{H}-5), 7.05$ (d, 2H, H-3' and H-5'), 6.99 (d, 2H, H-3"' and H-5"), 3.81 (s, 3H, MeO), 3.78 (s, 3H, MeO); MS (m/z) $432\left(\mathrm{M}^{+}\right)$; Anal. Calcd. for $\mathrm{C}_{22} \mathrm{H}_{20} \mathrm{~N}_{6} \mathrm{O}_{2} \mathrm{~S}: \mathrm{C}, 61.09 ; \mathrm{H}, 4.66, \mathrm{~N}$, 19.43. Found: C, 60.85; H, 4.50; N, 19.20.

2,4-Bis-(2-(3-Chlorobenzylidene)hydrazinyl)thieno[2,3-d] pyrimidine (11f): $66 \%$ Yield, mp $153-155^{\circ} \mathrm{C}$; IR (KBr) 3115 and $3080(\mathrm{NH}), 1460(\mathrm{C}=\mathrm{N}) \mathrm{cm}^{-1}$; ${ }^{1} \mathrm{H}$ NMR (DMSO- $\left.d_{6}\right) \delta 11.73$ (s, 1H, NH), $11.16(\mathrm{~s}, 1 \mathrm{H}, \mathrm{NH}), 8.28(\mathrm{~s}, 1 \mathrm{H}, \mathrm{N}=\mathrm{CH}), 8.11(\mathrm{~s}, 1 \mathrm{H}$, $\mathrm{N}=\mathrm{CH}), 7.85(\mathrm{~d}, 1 \mathrm{H}, J=5.9 \mathrm{~Hz}$, thiophene H-6), 7.76-7.74 (m, 2H, H-2' and H-2"), 7.59-7.37 (m, 6H, phenyl), 7.31 (d, $1 \mathrm{H}, J=5.9 \mathrm{~Hz}, \mathrm{H}-5)$; MS $(\mathrm{m} / \mathrm{z}) 441\left(\mathrm{M}^{+}\right)$; Anal. Calcd. for $\mathrm{C}_{20} \mathrm{H}_{14} \mathrm{Cl}_{2} \mathrm{~N}_{6} \mathrm{~S}$ : C, 54.43; H, 3.20, N, 19.04. Found: C, 54.29; H, 3.42; N, 18.89 .

2,4-Bis-(2-(3-methylbenzylidene)hydrazinyl)thieno[2,3- $d]$ pyrimidine (11g): $60 \%$ Yield, mp $206-208^{\circ} \mathrm{C}$; IR (KBr) 3110 and $3075(\mathrm{NH}), 1458(\mathrm{C}=\mathrm{N}) \mathrm{cm}^{-1} ;{ }^{1} \mathrm{H}$ NMR $\left(\mathrm{DMSO}-d_{6}\right) \delta 11.65$ (s, 1H, NH), 11.03 (s, 1H, NH), 8.65 (s, 1H, N=CH), 8.00 (s, $1 \mathrm{H}, \mathrm{N}=\mathrm{CH}), 7.95-6.91(\mathrm{~m}, 10 \mathrm{H}$, thiophene and phenyl), $2.41(\mathrm{~s}$, $3 \mathrm{H}, \mathrm{Me}), 2.35$ (s, 3H, Me); MS ( $\mathrm{m} / \mathrm{z}) 400\left(\mathrm{M}^{+}\right)$; Anal. Calcd. for $\mathrm{C}_{22} \mathrm{H}_{20} \mathrm{~N}_{6} \mathrm{~S}$ : C, 65.98; H, 5.03, N, 20.98. Found: C, 65.84; H, 4.84; N, 20.84.

2,4-Bis-(2-(3-bromobenzylidene)hydrazinyl)thieno[2,3-d] pyrimidine (11h): $63 \%$ Yield, mp $158-160{ }^{\circ} \mathrm{C}$; IR (KBr) 3115 and $3076(\mathrm{NH}), 1460(\mathrm{C}=\mathrm{N}) \mathrm{cm}^{-1} ;{ }^{1} \mathrm{H}$ NMR (DMSO- $\left.d_{6}\right) \delta 11.69$ $(\mathrm{s}, 1 \mathrm{H}, \mathrm{NH}), 11.18(\mathrm{~s}, 1 \mathrm{H}, \mathrm{NH}), 8.25(\mathrm{~s}, 1 \mathrm{H}, \mathrm{N}=\mathrm{CH}), 8.09(\mathrm{~s}, 1 \mathrm{H}$, $\mathrm{N}=\mathrm{CH}), 7.75(\mathrm{~d}, 1 \mathrm{H}, J=5.9 \mathrm{~Hz}$, thiophene $\mathrm{H}-6), 7.62(\mathrm{~m}, 2 \mathrm{H}$, H-2' and H-2"), 7.51-7.37 (m, 6H, phenyl), 7.30 (d, $1 \mathrm{H}, J=5.9$ $\mathrm{Hz}, \mathrm{H}-5)$; $\mathrm{MS}(\mathrm{m} / \mathrm{z}) 530\left(\mathrm{M}^{+}\right)$; Anal. Calcd. for $\mathrm{C}_{20} \mathrm{H}_{14} \mathrm{Br}_{2} \mathrm{~N}_{6} \mathrm{~S}$ : C, 45.30; H, 2.66, N, 15.85. Found: C, 45.48; H, 2.50; N, 15.70.

General procedure for the preparation of $6 \mathbf{a}-\mathbf{h}$. A mixture of 11a-h $(2 \mathrm{mmol})$ and $\mathrm{Ca}(\mathrm{OCl})_{2} / \mathrm{Al}_{2} \mathrm{O}_{3}(10 \mathrm{mmol}$ : grounded mixture in mortar of calcium hypochlorite; $10 \mathrm{mmol}, 1.43 \mathrm{~g}$ and neutral alumina; $1.43 \mathrm{~g})$ in dry dichloromethane $(20 \mathrm{~mL})$ was stirred rapidly at room temperature for $2 \mathrm{~h}$. After the reaction mixture was filtered, the filtrate was evaporated under reduced pressure. The resulting crude product was purified by recrystallization using a mixture of chloroform and ethanol. 
3,7-Diphenylthieno[3,2-e] bis [1,2,4]triazolo[4,3-a:4',3'-c] pyrimidine (6a): $70 \%$ Yield, mp $341-343{ }^{\circ} \mathrm{C} ;{ }^{1} \mathrm{H}$ NMR (DMSO$\left.d_{6}\right) \delta 8.08(\mathrm{~d}, 1 \mathrm{H}, J=5.9 \mathrm{~Hz}$, thiophene $\mathrm{H}-8), 8.06(\mathrm{~d}, 2 \mathrm{H}, \mathrm{H}-2$ ' and H-6'), 7.79-7.58 (m, 9H, H-2", H-6", thiophene H-9, H-3', H-4', H-5', H-3", H-4" and H-5"'); MS (m/z) 368 (M', 100), 264 (8), 103 (13), 77 (10); Anal. Calcd. for $\mathrm{C}_{20} \mathrm{H}_{12} \mathrm{~N}_{6} \mathrm{~S}: \mathrm{C}, 65.20$; H, 3.28, N, 22.81. Found: C, 64.98; H, 3.46; N, 22.68.

3,7-Bis(4-chlorophenyl)thieno[3,2-e]bis[1,2,4] triazolo[4, 3-a:4',3'-c]pyrimidine (6b): 79\% Yield, mp $179-181{ }^{\circ} \mathrm{C} ;{ }^{1} \mathrm{H}$ NMR (DMSO- $\left.d_{6}\right) \delta 8.11-8.08(\mathrm{~m}, 3 \mathrm{H}$, thiophene H-8, H-2' and H-6'), 7.78-7.76 (m, 4H, H-2', H-6', H-3' and H-4'), 7.72 (d, 2H, H-3" and H-4"), 7.61 (d, $1 \mathrm{H}, J=5.9 \mathrm{~Hz}$, thiophene $\mathrm{H}-9)$; MS (m/z) $437\left(\mathrm{M}^{+}, 100\right), 285$ (15), 151 (19), 103 (10); Anal. Calcd. for $\mathrm{C}_{20} \mathrm{H}_{10} \mathrm{Cl}_{2} \mathrm{~N}_{6} \mathrm{~S}$ : C, 54.93; H, 2.30, N, 19.22. Found: C, 55.19; H, 2.12; N, 19.08 .

3,7-Bis(4-methylphenyl)thieno[3,2-e]bis [1,2,4]triazolo[4, 3-a:4',3'-clpyrimidine (6c): $66 \%$ Yield, mp $271-273{ }^{\circ} \mathrm{C} ;{ }^{1} \mathrm{H}$ NMR (DMSO-d $\left.d_{6}\right) \delta 7.97$ (d, 2H, H-2' and H-6'), 7.77 (d, 1H, $J=5.9 \mathrm{~Hz}$, thiophene H-8), 7.63-7.57 (m, 3H, H-2", H-6" and thiophene H-9), 7.50 (d, 2H, H-3' and H-4'), 7.43 (d, 2H, H-3"' and H-4"), 2.49 (s, 3H, Me), 2.47 (s, 3H, Me); MS (m/z) 396 $\left(\mathrm{M}^{+}, 95\right), 265$ (19), 131 (15), 103 (8); Anal. Calcd. for $\mathrm{C}_{22} \mathrm{H}_{16} \mathrm{~N}_{6} \mathrm{~S}$ : C, 66.65; H, 4.07, N, 21.20. Found: C, 66.88; H, 3.89; N, 20.98.

3,7-Bis(4-bromophenyl)thieno[3,2-e]bis [1,2,4] triazolo[4, 3-a:4',3'-c]pyrimidine (6d): $70 \%$ Yield, mp $238-240{ }^{\circ} \mathrm{C} ;{ }^{1} \mathrm{H}$ NMR (DMSO- $\left.d_{6}\right) \delta 8.03$ (d, 2H, H-2' and H-6'), 7.93 (d, 2H, H-2" and H-6"), 7.85 (d, 2H, H-3' and H-4'), 7.80 (d, 1H, $J=5.9$ $\mathrm{Hz}$, thiophene H-8), 7.71 (d, 2H, H-3" and H-4"), 7.63 (d, 1H, thiophene H-9); MS (m/z) 526 (M+ , 75), 343 (20), 264 (22), 236 (32), 181 (50), 131 (15), 102 (100), 84 (50), 66 (61); Anal. Calcd. for $\mathrm{C}_{20} \mathrm{H}_{10} \mathrm{Br}_{2} \mathrm{~N}_{6} \mathrm{~S}$ : C, 45.65; H, 1.92, N, 15.97. Found: C, 45.79; $\mathrm{H}, 1.81 ; \mathrm{N}, 16.11$.

3,7-Bis(4-methoxyphenyl)thieno[3,2-e] bis [1,2,4]triazolo [4,3-a:4',3'-c]pyrimidine (6e): $72 \%$ Yield, mp $235-237^{\circ} \mathrm{C}$; ${ }^{1} \mathrm{H}$ NMR (DMSO-d $) \delta 8.04$ (d, 2H, H-2' and H-6'), 7.76 (d, 1H, $J=5.9 \mathrm{~Hz}$, thiophene H-8), 7.68 (d, 2H, H-2" and H-6"), 7.60 (d, 1H, thiophene H-9), 7.23 (d, 2H, H-3' and H-4'), 7.19 (d, 2H, H-3" and H-4"), 3.88 (s, 6H, $2 \mathrm{MeO})$; $\mathrm{MS}(\mathrm{m} / \mathrm{z}) 428\left(\mathrm{M}^{+}\right.$, 100), 295 (12), 133 (40), 103 (20), 90 (22); Anal. Calcd. for $\mathrm{C}_{22} \mathrm{H}_{16} \mathrm{~N}_{6} \mathrm{O}_{2} \mathrm{~S}: \mathrm{C}, 61.67 ; \mathrm{H}, 3.76, \mathrm{~N}, 19.61$. Found: $\mathrm{C}, 61.44 ; \mathrm{H}$, $3.59 ; \mathrm{N}, 19.71$.

3,7-Bis(3-chlorophenyl)thieno[3,2-e]bis[1,2,4] triazolo[4, 3-a:4',3'-c]pyrimidine (6f): $76 \%$ Yield, mp $203-205{ }^{\circ} \mathrm{C} ;{ }^{1} \mathrm{H}$ NMR (DMSO- $\left.d_{6}\right) \delta 8.30$ (s, 1H, H-2'), 8.19 (s, 1H, H-2"'), 8.09 (d, 1H, 4'), 7.96 (d, 1H, H-4"), 7.87-7.85 (m, 2H, H-6' and H-6"), 7.81 (d, $1 \mathrm{H}, J=5.9 \mathrm{~Hz}$, thiophene H-8), 7.74-7.68 (m, 3H, H-4', H-5' and H-4"), 7.64-7.61 (m, 2H, H-5" and thiophene H-9); MS ( $m / z) 437\left(\mathrm{M}^{+}, 95\right), 285$ (12), 151 (19), 103 (8); Anal. Calcd. for $\mathrm{C}_{20} \mathrm{H}_{10} \mathrm{Cl}_{2} \mathrm{~N}_{6} \mathrm{~S}$ : C, 54.93; H, 2.30, N, 19.22. Found: C, 54.76; $\mathrm{H}, 2.19 ; \mathrm{N}, 19.10$.

3,7-Bis(3-methylphenyl)thieno[3,2-e]bis[1,2,4] triazolo[4, 3-a:4',3'-c]pyrimidine (6g): $68 \%$ Yield, mp $95-97{ }^{\circ} \mathrm{C}$ (decompose); ${ }^{1} \mathrm{H}$ NMR (DMSO- $d_{6}$ ) $\delta$ 7.99-7.96 (m, 2H, H-6' and H-6"), 7.82 (d, 1H, J=5.9 Hz, thiophene H-8), 7.55-7.40 (m,
5H, thiophene H-9, H-2', H-2"', H-5' and H-5"'), 7.26-7.23 (m, 2H, H-4' and H-4"), 2.48 (s, 6H, $2 \mathrm{Me})$; MS (m/z) $396\left(\mathrm{M}^{+}\right.$, 90), 265 (19), 131 (10), 103 (12); Anal. Calcd. for $\mathrm{C}_{22} \mathrm{H}_{16} \mathrm{~N}_{6} \mathrm{~S}: \mathrm{C}$, 66.65; H, 4.07, N, 21.20. Found: C, 66.44; H, 3.90; N, 20.04.

3,7-Bis(3-bromophenyl)thieno[3,2-e]bis[1,2,4] triazolo[4, 3-a:4',3'-c]pyrimidine (6h): $72 \%$ Yield, mp $178-180{ }^{\circ} \mathrm{C} ;{ }^{1} \mathrm{H}$ NMR (DMSO- $\left.d_{6}\right) \delta 8.30$ (s, 1H, H-2'), 8.19 (s, 1H, H-2"), 8.09 (d, 1H, H-6'), 7.96 (d, 1H, H-6"), 7.94 (d, 1H, H-4'), 7.85 (d, $1 \mathrm{H}, \mathrm{H}-4$ ”), 7.78 (d, 1H, $J=5.9 \mathrm{~Hz}$, thiophene H-8), 7.55-7.46 (m, 3H, thiophene H-9, H-5' and H-5'); MS $(\mathrm{m} / \mathrm{z}) 526\left(\mathrm{M}^{+}\right.$, 70), 236 (30), 181 (59), 102 (95), 84 (40), 66 (39); Anal. Calcd. for $\mathrm{C}_{20} \mathrm{H}_{10} \mathrm{Br}_{2} \mathrm{~N}_{6} \mathrm{~S}$ : C, 45.65; H, 1.92, N, 15.97. Found: $\mathrm{C}, 45.49$; $\mathrm{H}, 1.85 ; \mathrm{N}, 15.80$.

\section{References and Notes}

1. El-Hawash, S. A.; Habib, N. S.; Fanaki, N. H. Pharmazie 1999, 54,808 .

2. Dickinson, R. P.; Bell, A. W.; Hitchcock, C. A.; Narayama-Swami, S.; Ray, S. J.; Richardson, K.; Troke, P. F. Bioorg. Med. Chem. Lett. 1996, 6, 2031.

3. Palaska, E.; Sahin, G.; Kelicen, P.; Durlu, N. T.; Altinok, G. Farmaco 2002, 57, 101.

4. Tehranchian, S.; Akbarzadeh, T.; Fazeli, M. R.; Jamalifar, H.; Shafiee, A. Bioorg. Med. Chem. Lett. 2005, 15, 1023.

5. Nagamatsu, T.; Ahmed, S.; Hossion, A. M. L.; Ohno, S. Heterocycles $\mathbf{2 0 0 7}, 73,777$.

6. Shawali, A. S.; Hassaneen, H. M.; Shurrab, N. K. Tetrahedron 2008, 64, 10339 .

7. Prakash, O.; Kumar, R.; Tyagi, P.; Kuhad, R. C. Eur. J. Med. Chem. 2007, 42, 868 .

8. Joe, B. S.; Son, H. Y.; Song, Y.-H. Heterocycles 2008, 75, 3091.

9. (a) Gibson, M. S. Tetrahedron 1963, 19, 1587. (b) Pollak, A.; Tišler, M. Tetrahedron 1966, 22, 2073. (c) El-Gazzar, A. B.; Hassan, N. A. Molecules 2000, 5, 835 .

10. Abdel-Fattah, B.; Kandeel, M. M.; Abdel-Hakeem, M.; Fahmy, Z. M. J. Chin. Chem. Soc. 2006, 53, 403.

11. Bower, J. D.; Doyle, F. P. J. Chem. Soc. 1957, 727.

12. Hozein, Z. A.; Atta, F. M.; Hassan, Kh. M.; Abdel-Wahab, A. A.; Ahmed, S. A. Synth. Commun. 1996, 26, 3733.

13. Shawali, A. S.; Hassaneen, H. M.; Shurrab, N. K. Heterocycles 2008, $75,1479$.

14. Shawali, A. S.; Gomha, S. M. Tetrahedron 2002, 58, 8559.

15. Bourgeois, P.; Cantegril, R.; Chene, A.; Gelin, J.; Mortier, J.; Moyroud, J. Synth. Commun. 1993, 23, 3195.

16. Ciesielski, M.; Pufky, D.; Döring, M. Tetrahedron 2005, 61, 5942.

17. (a) Song, Y.-H.; Son, H. Y. J. Heterocycl. Chem. 2010, 47, in press. (b) Lee, H. M.; Song, Y.-H. Bull. Korean Chem. Soc. 2010, 31, 185. (c) Son, H. Y.; Song, Y.-H. J. Kor. Chem. Soc. 2010, 54, 350. (d) Jo, B. S.; Song, Y.-H. Synth. Commun. 2009, 39, 4407. (e) Song, Y.-H.; Jo, B. S. J. Heterocycl. Chem. 2009, 46, 1132. (f) Song, Y.-H.; Jo, B. S.; Lee, H. M. Heterocycl. Commun. 2009, 15, 203. (g) Song, Y.-H.; Jo, B. S. Bull. Korean Chem. Soc. 2009, 30, 969. (h) Lee, H. M.; Song, Y.-H. J. Kor. Chem. Soc. 2009, 53, 387. (i) Song, Y.-H.; Seo, J. J. Heterocycl. Chem. 2007, 44, 1439. (j) Song, Y.-H. Heterocycl. Commun. 2007, 13, 33.

18. Shiho, D.; Tagami, S. J. Am. Chem. Soc. 1960, 82, 4044.

19. Robba, M.; Lecomte, J.-M.; Cugnon de Sévricourt, M. Comptes rendus 1968, 266 (Serie C), 128.

20. Jourdan, F.; Renault, J.; Karamat, A.; Ladurée, D.; Robba, M. J. Heterocycl. Chem. 1995, 32, 953. 